Animal, Poultry and Fish Production Research

http:/www.journals.zu.edu.eg/journalDisplay.aspx?Journalld=1\&queryType=Master

\title{
OSTRICH BREEDING IN CHINA
}

\author{
Mohamed A.M. Okasha ${ }^{1 *}$, A.I. Attia ${ }^{2}$ and K.M. Mahrose ${ }^{3}$ \\ 1. Nat. Res. Dept., Inst. Asian Studies and Res., Zagazig Univ., Egypt \\ 2. Poult. Dept., Fac. Agric., Zagazig Univ., Zagazig, Egypt \\ 3. Anim. and Poult. Dept., Fac. Technol. and Dev., Zagazig Univ., Egypt
}

Received: 13/02/2019 ; Accepted: 28/07/2019

\begin{abstract}
Ostrich (Struthio camelus) has become one of the valuable agricultural enterprises in many countries of the world. China has become Asian's number one ostrich species raiser with about 20,000 ostrich bred farms. China started in 1992 to import some ostrich species from South Africa. Ostrich was raised globely since the 1980s for its feathers, meat, egg, hair and bone are all of high economic value. China's progress in producing ostriches has improved it's rank from fifth to the second globely in recent years, due to the following factors: The area of pastures which reached $40 \%$ of the area of China.Large amounts of agricultural wasts. China has been producing iron and thus has produced the cheapest agricultural machines, such as irrigation machines, cutting and pressing the feed. China achieved progress in the electronical industries which have enabled it to produce hatchery machines to promote the poultry industry. China is making use of solar energy and producing cheap energy used to irrigate agricultural land and operate farm machinery. Thus, the price of feed is cheap and therefore it costs to feed the ostriches as little as possible.Use of seawater desalination technology and cultivation of saline-tolerant fodder crops such as fodder beat, bonicam and blubank .The use of leather processing tectology and production of the finest leather industries of shoes and bags .China has imported large amounts of ostriches from South Africa and used the best breeding and ostrich production systems in South Africa. The most important factors leading to the success of the ostrich industry in china are limited into three factors. First: Nutrition and cheap feed should be provided by planting enough alfalfa. Using solar energy to irrigate these lands. Sowing saline and drought tolerant genotypes, such as blubanks and bonecam, as well as machines for cutting and making pellet for green feed. Second: Hatching Third: Health.
\end{abstract}

Key words: Egg, handling, hatchability, incubation, management, ostrich.

\section{INTRODUCTION}

Ostrich (Struthio camelus) has become one of the valuable agricultural enterprises and has now become an important commercial species in many countries of the world (Mahrose, 2007; Jelgat, 2009; Mahrose et al., 2016; Abbas et al., 2018). Recent interest in ostrich farming has led to an increasing demand for information about this bird and how to manage it in a commercial environment (Cooper et al., 2008; El-Safty and Mahrose, 2009; Mahrose, 2012; Mahrose et al., 2015; Mahrose et al., 2019).
Rising demand is attributed to the low content of energy, total lipids, cholesterol and saturated fat, and the high content of protein and iron relative to that of beef, veal, pork, lamb, poultry, rabbit and horse meat (Alhomaid and Ali, 2013). Therefore, the specific goal of this work is to give a spotlight on the ostrich farming in China.

China has become Asian's number one ostrich raiser with about 20,000 ostriches bred farms (Zhang et al., 2002 and Xinhua, 2004). The same authors added that China started in 1992 to import some ostrich species that was indigenous to Africa. China imported four

\footnotetext{
* Corresponding author: Tel. : +01098388008

E-mail address: doctor_mohamedokasha@yahoo.com
} 
ostrich breeds: Black Neck (African Black), Blue Neck, Red Neck and Australian Grey, as two hens to one rooster as a production unit in the breeding farms (Zhang et al., 2002). Fossil remains of ostriches have been found in lower pliocene formations in Pao Te Hsien, NorthWest Shan'xi, on the Yellow River, China; and fossil eggs have been found in a region from NorthNorthWest to South-Southwest of Kalgan on the border of Shan'xi and Inner Mongolia (Abbas et al., 2018). The ancient Chinese had heard about its existence in the Middle East, and eggs and even living birds were occasionally sent to the imperial court from Persia and neighboring countries (Buffetaut and Angst, 2017). There are no more wild ostriches in China as fossil remains have been found, where ostriches have disappeared from a large part of their range for perhaps a million years (Zhang, 2000).

The most important factors leading to the success of the ostrich industry are limited into three factors as previously: illustrated.

First: Nutrition and cheap feed should be provided by planting alfalfa in enough acreage. Solar energy was used to irrigate these lands. Sowing saline and drought tolerant genotypes, such as blubanks and bonecam, as well as using machines for cutting and pressing green feed were used.

Second: Hatching compared with chickens, the artificial incubation requirements of ostrich eggs are poorly understood, which is considered to be well below that achieved in the natural nests of ostriches (Burger and Bertram, 1981; Faki et al., 2015). Ostrich egg incubation is still the unique most important factor affecting productivity which is still incompletely known. Artificial incubation is considered to be the only way to get good results in ostrich production because the natural incubation not suitable to commercial ostrich production on any significant scale (Hallam, 1992). Hatchability percentages of ostrich eggs in Australia and England is reported to be less than $50 \%$, while it ranged from $35 \%$ to $70 \%$ in South Africa (Horbanczuk and Sales, 1998). The maximum values for hatchability of ostrich eggs are poor as around $60 \%$, while hatchability of fertile eggs is high, as at best only around $70 \%$ of fertile eggs are producing live chicks (Deeming and Ar, 1999; Van Schalkwyk et al., 2000). Bunter et al.
(2001) concluded that the number of produced chicks was highly correlated with egg production. Low hatchability of ostriches is well known and many chicks that do hatch subsequently die (Mahrose, 2007). The factors that affect hatchability including egg hygiene, egg storage conditions and period, incubation temperature, humidity, egg orientation, egg turning, ventilation and sanitation. Incubation temperature ranges from $35.9-36.5^{\circ} \mathrm{C}$ ) (Wilson, 2003). Estimated relative humidity requirements are $15-20 \%$ during incubation and 40\% during hatching. Optimal turning frequency has not been determined for ostrich fertile eggs. However, better results can be achieved by turning the eggs once per hour automatically. Levels of oxygen and carbon dioxide that need to be maintained in the incubator for ostrich eggs are $21 \%$ and $0.05-0.10 \%$ respectively. Egg weight loss during incubation is important if high hatchability is to be achieved where an egg weight loss of $12-17 \%$ during the 38 days of incubation is recommended for ostrich eggs. The major factors contributed to egg weight loss are shell porosity, relative humidity, egg size and incubation temperature (Wilson, 2003).

Low hatchability could be caused by poor control of incubation parameters (temperature, humidity, air circulation, egg position and turning), improper egg handling (egg collection, egg washing methods, improper egg storage) and egg quality (egg size, nutrients in eggs, shell thickness and porosity) (Cooper, 2001). the nutritional status of female ostriches and microbial contamination of the egg .affect the hatchability and subsequent survival rate of chicks. However, oedemas and malposition are key factors causing embryo mortality, particularly when the head of the embryo is positioned at the end of the egg away from the air space, death in embryos was caused by severe oedema (45\%) alone and in combination with malpositioning $(55 \%)$ during the last 10-14 days of incubation (Ley et al., 1986).

\section{Egg Quality}

Ostrich egg weight ranges from 350 to over 2200 g.but ostrich egg weighs range of 1300 to $1700 \mathrm{~g}$ gives the best hatchability. Ideally, incubating eggs of similar weight in the same batch will yield good results as the incubation conditions are easier to maintain. Extremely 
large and small eggs have lower hatchability due insufficient weight loss during incubation. Egg weight loss during the incubation is $8.8-19.7 \%$, and $15.6 \%$ in nature and weight loss of $13-15 \%$ during artificial incubation is preferable (Mahrose, 2007). Eggshell thickness also affects hatchability and egg pore density of ostrich eggs is positively related to egg weight loss and hatchability. Eggshell thickness is not related to egg size, but medium sized eggs had significantly higher eggshell porosity (number of large pores per $\mathrm{cm}^{2}$ of shell), higher egg weight loss and higher hatchability as compared to small or large eggs (Gonzales et al., 1999).

\section{Time of Egg Collection}

Eggs should be collected several times a day with the last collection at sundown that eggs should collected 10- 15 minutes after laying (Cooper, 2001). Eggs left in the nest are frequently rolled, damaged or even eaten by adults and increases susceptibility to bacterial infection, particular when left overnight (Stewart, 1996). Eggs collected in the evening resulted in lower mortality of chicks than collected next morning (Van Schalkwyk, 1998). Immersion sanitization of the egg shell does not improve hatchability of internally contaminated eggs. Large numbers of eggs should be placed in padded crates to minimize shaking during transport. Eggs should be handled with disposable gloves or a plastic bag or sterile towel to prevent possible contamination (Cooper, 2001).

\section{Egg Cleaning}

Keeping eggs clean is an effective way to prevent contamination. Nests should be located away from feeding areas to reduce faecal contamination (Copper, 2001). Sand should place in the nests and regularly replaced to keep the nests clean and dry. A common practice is to remove adherent dirt on the egg with a dry cloth or sand paper when collected (Glatz, 2000). A dry egg should be lightly buffed with a softbristle brush only on specific areas to remove adherent dirt without destroying the cuticle. Eggs may be carefully rinsed, sprayed, or immersed in warm solutions, including sodium hypochlorite, chlorhexidine, quaternary ammonium compounds or phenolics. However, these methods may damage the cuticle and lower resistance to subsequent bacterial contamination. If the egg is wet or contaminated, the surface is dried with a blow drier and then buffed. The eggs can be air dried and placed in storage. In the domestic poultry industry, the egg surface is coated with a fine layer of commercial disinfectant solution containing either a quaternary ammonium or phenolic compound formulated to prevent contamination (Stewart, 1996). Disinfectants are applied either by a hand spray, aerosol, or by fogging. And should not produce any residue on the shell surface which may interfere with air exchange through pores during incubation (Glatz, 2000). Severely contaminated eggs can be washed by immersed in a $37.8^{\circ} \mathrm{C}$ phenolic or quaternary ammonium solution for 30-45 seconds, but the procedure may reduce hatchability by encouraging movement of micro-organisms from the surface into the interior of the egg. Eggs are rinsed in clean water and dried using a sterile towel (Shane and Minteer, 1896). The eggs can be safely cleaned by a dry cloth first and then lightly mist-sprayed with $5 \mathrm{~g} / 1$ of a Virkon solution (Cooper, 2001). Hatchability percentage is higher and late embryonic death was lower for the eggs disinfected by UV as compared to eggs washed using a peroxigen powder compound and quaternary ammonium (Van Shalkwyk et al., 1997).

\section{Storage}

Ostrich eggs are normally stored for up to a week before being artificially incubated. But at the start and the end of the season, storage may be even longer in order to ensure that sufficient eggs are available (Deeming and Ar, 1999). Hatchability mean percentage was higher in eggs stored less than or equal to10 days than eggs stored $>15: 24$ days, but hatchability of eggs stored $>10$ is less than or equal to 15 days was not different from eggs stored is less than or equal to 10 or $>15: 24$ days as noted by Hassan et al. (2005). They added that the most effective storage period was less than 15 days to maintain hatchability for ostrich eggs when incubated at 36.5 to $37.0^{\circ} \mathrm{C}$ with $25 \% \mathrm{RH}$. There is no standard method to store ostrich eggs in terms of temperature, humidity and turning. Embryos start to develop at $29.4^{\circ} \mathrm{C}$ but ostrich eggs held at or above this temperature degree showed an 
increase in early embryonic mortality after the second day of incubation, can be stored for 7 days under UV lighting but Eggs maintained between $12.8^{\circ} \mathrm{C}$ and $18.3^{\circ} \mathrm{C}$ may be safely stored for 7 days, but hatchability will be significantly reduced after 10 days. Bertram (1979) found that eggs can be safely stored up to 10 days at $18^{\circ} \mathrm{C}$ and $69 \%$ RH. Nahm (2001) found that egs can be safely stored up to 19days at $15.5-15.6^{\circ} \mathrm{C}$ without controlling the humidity. RH near $75 \%$ is recommended to prevent water loss from eggs during storage. Hassan et al. (2004) recommended storage $\mathrm{RH}$ should be around $35 \%$ to prevent the development of over hydrated chicks. Eggs should be turned daily or rotated $180^{\circ}$ once daily (Mahrose, 2007).

\section{Incubation Temperature}

Eggs can be successfully incubated over the range $35.0-37.0^{\circ} \mathrm{C}$. The optimum incubation temperature is $36.4^{\circ} \mathrm{C}$. Increasing incubation temperature from 36.0 to $37.2^{\circ}$ will reduce hatchability from 73 to $44 \%$. Horbanczuk (2002) claimed that the length of the incubation is principally associated with temperature. Hassan et al. (2004) noted that when temperature increased from 36.5 to $37.5^{\circ} \mathrm{C}$ incubation period decreased from 41.51 to 39.34 days.

\section{Incubation Humidity}

Ideally, the actual humidity level used to incubate ostrich eggs should be based on the average of weight loss for all eggs produced from the flock. To get a weight loss of $13.4 \%$ to 39 days of incubation, RH should be less than 30-35\% during incubation (Abbas et al., 2018). Insufficient egg weight loss or the lowest weight losses $(<7 \%)$ and highest weight losses $(>17 \%)$ will result in low hatchability with deficient chicks.

\section{Air Circulation and Ventilation}

Circulation is the movement of air within the incubator. As air flow rate in the incubator is about $45 \mathrm{~L} / \mathrm{hr}$./egg. Ventilation is required to supply oxygen and reduce carbon dioxide level in the incubator. However, there is lack of information on ostrich incubation ventilation. Recommendations for commercial poultry incubation are above $20.5 \%$ of oxygen and below $0.5 \%$ of carbon dioxide. Hatchability was reduced by about $5 \%$ for each $1 \%$ decrease in oxygen and above $0.5 \% \mathrm{CO}_{2}$ in the incubation air can increase embryonic death (Abbas et al., 2018).

\section{Position and Turning of Eggs}

Deeming (2009) recommended that vertical setting eggs and rotated through $90^{\circ}$ around the short axis will produce acceptable hatchability. The same author added that turning eggs during incubation improves hatchability by stimulating the growth of the embryo preventing the embryo attaching to the inner shell membrane and providing a uniform temperature. The eggs should be turned at least twice daily ( 8 to 10 times per day is better) until 39days when the eggs are transferred to the hatcher.

\section{Rearing Systems}

\section{Intensive rearing}

Stocking density needed by ostrich chicks depends on the type of housing but Semiintensive rearing of birds is the most widely used method and even during intensive keeping of ostriches in controlled environment houses it is advisable to let them out to minimize occurrence of leg problems (Du Preez, 1991). Chicks are kept indoors during the first 3-7days with a rearing temperature of $26-32^{\circ} \mathrm{C}$, thereafter they are moved out onto pastures during the 3-7 days. Under this system, chicks can be kept in the rearing house until 3-4 weeks of age where $30-50$ chicks are kept in a $3 \times 3 \mathrm{~m}$ enclosure and $3 \times 10 \mathrm{~m}$ exercise area for 4 weeks. Then birds are moved to large areas $(25 \times 25 \mathrm{~m})$ with heated shelters $\left(22^{\circ} \mathrm{C}\right)$. Outdoor enclosures can be made of timber or steel posts sheets with $75 \%$ shade cloth about 1.0-1.2 $\mathrm{m}$ high is sufficient to keep ostrich chicks up to 12 weeks of age (Tuckwell, 1997).

\section{Semi-intensive}

In this system, 25- 50 days old ostrich chicks are raised on pasture (usually lucern) with $45 \mathrm{~cm}$ high fences until about 6 weeks. A concentrate diet is provided and chicks are kept in a shelter with heating during the night. Movable shelters are common which enable birds to have access to fresh pasture. Birds of about 6 weeks of age will be moved to a large enclosure which can hold 150 birds and fed on chopped lucern and concentrates (Verwoerd et al., 1999). 


\section{Proper flooring}

It is important for bedding to reduce ostrich chick mortality, therefore rough concrete or concrete covered with rubber mats, or galvanized welded mesh raised $2-100 \mathrm{~cm}$ above the floor. The floor is concrete (Mahrose, 2007) with dry hay bedding covered by mesh to stop hay ingestion and to separate the chicks from urine

\section{Heating for Chicks}

\section{Temperature}

In a commercial farming environment, ostrich chicks are normally kept in the hatcher or brooder at a temperature about $32^{\circ} \mathrm{C}$ for $1-2$ days after hatching (Deeming et al., 1996). However, temperatures used for young ostrich chicks vary from $21-26.5^{\circ} \mathrm{C}$ to $32-35^{\circ} \mathrm{C}$ in the industry. It recommended that the youngest chicks should be raised under temperature starting around $30^{\circ} \mathrm{C}$ with a drop of $0.5^{\circ} \mathrm{C}$ each day until reach $26^{\circ} \mathrm{C}\left( \pm 1^{\circ} \mathrm{C}\right)$ (Verwored et al., 1999). However, the whole brooder room is heated by domestic oil heaters and temperature maintained above $30^{\circ} \mathrm{C}$ for $2-7$ days. Heating sources can be infrared light, ceramic oil, gas lamp or electrical heaters thermostat control of temperatures is crucial to prevent overheating (Verwoerd et al., 1999).

\section{Feeding Chicks}

Absorption of the yolk sac provides nutrients for ostrich chicks for the first few days, that chicks can be kept without food and water for 68 days after hatching. The chopped fresh lucern fed with starter diets will stimulate intake of food, the place should be free of wire or sticks which can be ingested and penetrate the proventriculus, resulting in death. Rapid growth over 2-4 months of age results in leg deformation which eventually leads to the death of some ostrich chicks with mortality rates as high as of $41.20 \%$ therefore, high fiber diets and more exercise may be help to reduce the mortality (Cooper et al., 2005; Elhashmi et al., 2011).

The development of ostrich industry is hampered by inadequate knowledge of nutritional requirements of this species, particularly those pertaining to the early-life stage (Iji, 2005;
Dube et al., 2009). Nutrition is an important part of poultry and ratite management. So, knowledge of nutrient needs during the various stages of growth, development and production of the ostrich are vital (Cooper et al., 2005; Carstens et al., 2014). Nutrition of ostrich chicks must be correct, as they are most vulnerable up to the age of 3 months (Cooper, 2004). In order to increase profitability of ostriches, determination of nutrient requirements of ostriches are essential (Cilliers et al., 1998). The inclusion of protein in feeds needs to be optimized for optimum performance as well as to minimize wastage (Engku Azahan and Noraziah, 2011). Ostriches require rations with high protein content, an essential ingredient for optimum growth and development (Cooper, 2004). Feeding costs are the largest expense in an ostrich production system, and protein is one of the more expensive components of the diet (Carstens et al., 2014). Diverse recommendations concerning the protein content in starter diets $(14.6-22 \% \mathrm{CP})$ of ostriches has been reported. Most ratite growers feed diets that contain 17$24 \%$ crude protein during brooding and growing (Cilliers, 1998).

\section{Ostrich Health}

Ostriches may be infected by viruses carried by wild birds and other animals which interact with them. Farmers should be aware of signs of illness, including staying alone, standing hunched up, laying down on, lethargy, not eating, loss of vigour, changes in faeces or urine, vomiting, coughing, panting, lameness, dull, brittle feathers and swelling on the body or legs (Muvhali, 2018). Maintaining good hygiene, proper housing and brooding and adequate stocking rate can improve ostrich welfare and production. Ostriches are susceptible to diseases found in avian species (Abbas et al., 2018). Contact with wild birds or commercial poultry, environmental stresses including high stocking density and poor hygiene could cause infections. Most diseases are related to farm management including feed and water supply, climate, stress, hygiene and incubator/brooder management. Proper management of these areas can reduce the risk of disease infection. For example, viruses bacterial fungal and parasitic diseases 


\section{REFERENCES}

Abbas, G., O. Zahid, M.S. Khan, M. Sajid, M. Asif and H. Saeed (2018). Future of ostrich Farming in Pakistan. Advances in Zool. and Botany, 6 (2): 55-65.

Alhomaid, F.A. and H.A. Ali (2013). Histological observations on the proventriculus and duodenum of African ostrich (Struthio Camelus) in relation to dietary vitamin A. Life Sci. J., 10 (2): 479-486.

Bertram BCR (1979) Ostriches recognize their own eggs and discard others. Nature 279, 233-234.

Buffetaut, E. and D. Angst (2017). How large was the giant ostrich of China? EVOLUÇÃORevista de Geistória e Pré-História, 2(1): 6-8.

Bunter, K.L., S.W.P. Cloete, S.J. van Scalkwyk and H.U. Graser (2001). Relationships between measures of productive performance in farmed ostrich hens. Proc. Assoc. Advmt. Anim. Breed. Genet., 14: 47- 50.

Burger, A.E. and B.C.R. Bertram (1981). Ostrich eggs in artificial incubation: could their hatching success be improved? South Afr. J. Sci., 77: $188-189$.

Carstens, P.D., A.R. Sharifi, T.S. Brand and L.C. Hoffman (2014). The growth response of ostrich (Struthio camelus var. domesticus) chicks fed on diets with three different dietary protein and amino acid concentrations. British Poult. Sci., 55: 510 - 517.

Cilliers, S.C. (1998). Feedstuff evaluation, metabolizable energy and amino acid requirements for maintenance and growth in ostriches. In: Proc. $2^{\text {nd }}$ Int. Sci. Ratite Cong., Oudtshoorn, South Afr., 12-23.

Cilliers, S.C., J.P. Hayes, A. Chwalibog, J. Sales and J.J. Du Preeze (1998). Determination of energy, protein and amino acid requirements for maintenance and growth in ostriches. Anim. Feed Sci. and Technol., 72: 283 - 293.

Cooper RG (2001). Handling, incubation, and hatchability of ostrich (struthio camelus var. domesticus) eggs: a review. Journal Applied Poultry Research 10, 262-273.
Cooper, R.G. (2004). Ostrich (Struthio camelus) chick and grower nutrition. Anim. Sci. J., 75: $487-490$.

Cooper, R.G., E.R. Lwanger and Kh.M. Mahrose (2005). Nutrition of ostrich (Struthio camelus Var. domesticus) breeder birds. Anim. Sci. J., 76: 5 - 10.

Cooper, R.G., Kh.M. Mahrose, M. El-Shafei and I.F.M. Marai (2008). Ostrich (Struthio camelus) production in Egypt. Tropical Anim. Health and Prod., 40: 349 - 355.

Deeming, D.C. (2009). The role of egg turning during incubation. Avian Biol. Res., 1: 6771.

Deeming DC, Dick ACK, Ayres L (1996) Rearing ostrich chicks-a stockman's guide. Ratite Conference, Oxfordshire, UK.

Deeming, D.C. and A. Ar (1999). Factors affecting the success of commercial incubation, In: Deeming, DC (Ed), The ostrich, biology, production and health, CABI publishing, Univ. Manchester.

Dube, S., E. Mwenje and E. Kambasha (2009). Studies of the effects on ostrich growth, of silage, altering feed levels and some nutritional supplements in feed. Int. J. Poult. Sci., 8 (12): 1132-1136.

Du Preez, J.J. (1991). Ostrich nutrition and management. In: Farrell, D.J. (ed.), Recent Advances in Anim. Nutr. in Aust., New England Univ., Armidale, Aust., 278 - 291.

Elhashmi, Y.H., O.H. Arabi, T.K. Taha and O.A. Eidam (2011). Growth and development of muscles, bones and fat of red-necked ostrich (Struthio camelus). Online J. Anim. and Feed Res., 1(6): 417-422.

El-Safty, S. and Kh.M. Mahrose (2009). Evaluation of some phenotypic, physiological and egg quality traits of African black neck ostrich under arid desert conditions of Libya. Int. J. Poult. Sci., 8: 553 - 558.

Engku Azahan, E.A. and M. Noraziah (2011). Evaluation of dietary protein intake by growing ostriches. Asian J. Poult. Sci., 5: 102 -106 . 
Faki, A.E., E.A.E. Obeid, H.I.M. Osman and A.D.E. Amin (2015). Ostrich (Struthio camelus) egg embryonic death during artificial incubation. Int. J. Appl. Sci. and Biotechnol., 3 (4): 566-578.

Glatz, P.C. (2000) A benchmark study of husbandry, transport, lairage and slaughter methods to improve skin quality of ratites; Vol 1 Ostriches. A report for the Rural Industries Research and Development Corporation. Australia.

Gonzales, A., D.G. Satterlee, F. Moharer and G.G. Cadd (1999). Factors affecting ostrich egg hatchability. Poult. Sci., 78: 1257-1262.

Hallam, M.G. (1992). The Topaz introduction to practical ostrich farming. Ostrich Producer's Association of Zimbabwe, Topaz, Harare, Zimbabwe.

Hassan, S.M., A.A. Siam, M.E. Mady and A.L. Cartwright (2004). Incubation temperature for ostrich (Struthio camelus) eggs. Poult. Sci., 83 (3): 495-499.

Hassan, S.M., A.A. Siam, M.E. Mady and A.L. Cartwright (2005). Egg storage period and weight effects on hatchability of ostrich (Struthio camelus) eggs. Poult. Sci., 84 (12): 1908 - 1912.

Horbanczuk, J.O. (2002). The ostrich. ISBN 83916046-5-9, Warsaw, Poland.

Horbanczuk, J.O. and J. Sales (1998). Effective artificial incubation ostrich eggs. World Poult., Elsevier, 14 (7): 20-21.

Iji, P.A. (2005). Anatomy and digestive physiology of the neonatal ostrich (Struthio camelus) in relation to nutritional requirements. Recent Advan. Anim. Nutr., 15: 165 - 170.

Jelgat, C.V. (2009). Studies on the possible causes of losses in ostrich production in selected ostrich farms in Kenya. M.Sc. Thesis, Fac. Vet. Med., Nairobi Univ., Kenya.

Ley, D.H., R.E. Morris, J.E. Smallwood and M.R. Loomis (1986). Mortality of chicks and decreased fertility and hatchability of eggs from a captive breeding pair of ostriches. J. Ame. Vet. Med. Assoc., 189: 1124-1126.
Mahrose, Kh.M. (2007). Some managerial studies on ostrich under Egyptian conditions. Ph.D. Thesis, Fac. Agric., Zagazig Univ., Egypt.

Mahrose, Kh.M. (2012). Influences of stocking density and male: female ratio on the performance of ostrich under desert conditions of Egypt. The $3^{\text {rd }}$ Mediterranean Poultry summit of WPSA ( $3^{\text {rd }}$ MPS) and the $6^{\text {th }}$ Int. Poult. Conf. ( $6^{\text {th }}$ IPC), Porto-Marina, Alex., Egypt, 26-29 March.

Mahrose, Kh.M., M.E. Abd El-Hack and Sh. Amer (2019). Effects of dietary crude protein levels and stocking density on growth performance and body measurements of ostrich chicks. Accepted for Public. Ann. Brazilian Acad. Sci.

Mahrose Kh.M., A.I. Attia, I.E. Ismail, D.E. Abou-Kassem and M.E. Abd El-Hack (2015). Growth performance and certain body measurements of ostrich chicks as affected by dietary protein levels during 2-9 weeks of age. Open Vet. J., 5:98-102.

Mahrose, Kh.M., M.A. Elsayed, H. Basuony and N. Gouda (2016). Effects of exposing ostrich eggs to doses of gamma radiation on hatchability, growth performance, and some blood biochemicals of hatched chicks. Environ. Sci. and Pollution Res., DOI 10.1007/s11356-016-7539-7.

Muvhali, F.T. (2018). Improving ostrich welfare by developing positive human-animal interactions. M.Sc. Thesis, Stellenbosch Univ., South Afr.

Nahm, K.H. (2001). Effects of storage length and weight loss during incubation on the hatchability of ostrich eggs (Struthio camuelus). Res. Note. Poult. Sci., 80 : 16671670.

Stewart, J.S. (1996) Hatchery Management in Ostrich Production. In 'Ratite Management, Medicine and Surgery'. (Eds TN Tully Jr., SM Shane) pp. 59-66. (Krieger Publishing Company, Malabar, Florida USA.)

Shane, S.M. and L. Minteer (1996). Biosecurity and Control of Disease. In Ratite 
Management, Medicine and Surgery. (Eds TN Tully Jr., SM Shane) pp. 31-36. (Krieger Publishing Company, Malabar, Florida USA.

Tuckwell, C. (1997). The New Rural IndustriesA handbook for farmers and investors. Rural Industries Res. and Dev. Corporation, Aust.

Van Schalkwyk, S.J., Z. Brand, S.W.P. Cloete and J.R. Blood (1997). The influence of different disinfection protocols on the hatching performance of ostrich eggs. In Proc. $2^{\text {nd }}$ Ed. Int. Ratite Conf., (Oudtshoorn, South Afr.), 157 - 158.

Van Schalkwyk, S.J. (1998). Improvement of fertility and hatchability of artificially incubated ostrich eggs in the Little Karoo. M Sc dissertation, Rhodes Univ., Grahamstown

Van Schalkwyk, S.J., S.W.P. Cloete, C.R. Brown and Z. Brand (2000). Hatching success of ostrich eggs in relation to setting, turning and angle of rotation. British Poult., Sci., $41: 46-52$.
Verwoerd, D.J., D.C. Deeming, C.R. Angel and B. Perelman (1999). Rearing environments around the world. In 'The Ostrich: Biology, production and health'. (Ed DC Deeming) (CABI Publishing, CAB Int., Wallingford, Oxon, United Kingdom), 163-206.

Wilson, H.R. (2003). Incubation and hatching of ratites. One of a series of the animal science department, florida cooperative extension service, Inst. Food and Agric. Sci., Univ. Florida.

Xinhua (2004). China becomes largest ostrich raiser in Asia. http://en.people.cn/ 200404/ 05/eng20040405_139425.shtml, accessed on January 12, 2019.

Zhang, L. (2000). A new system for ostrich production in China, XVIII World Poultry Congress.

Zhang, I., I. Ke, P. Yao and S. Huang (2002). Ratite industry in China. $7^{\text {th }}$ World Congress on Genetics Appl. to Livestock Prod., August 19-23, 2002, Montpellier, France. 


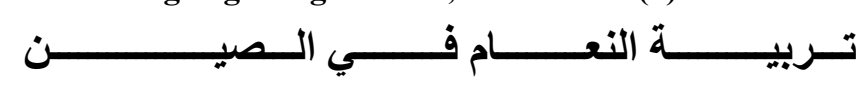

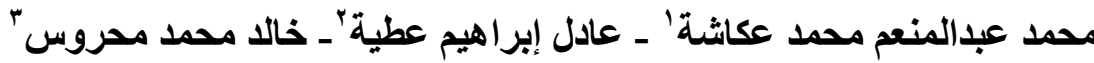

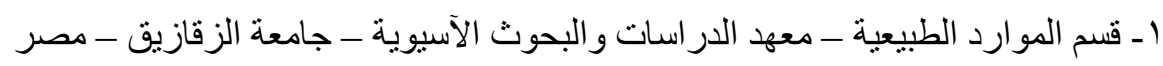

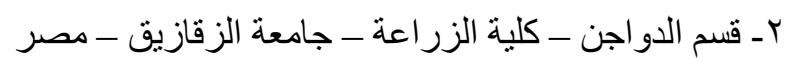

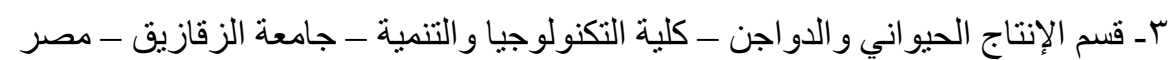

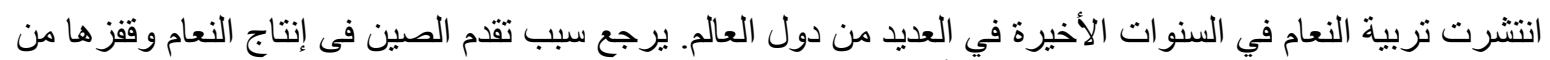

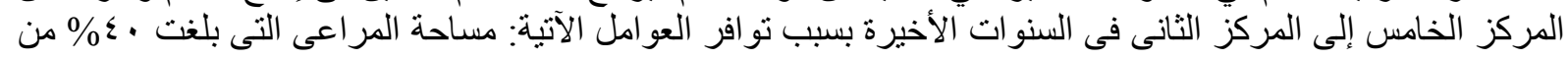

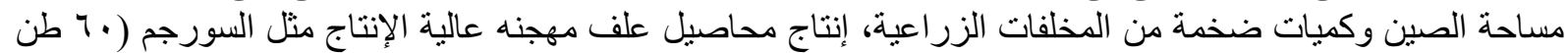

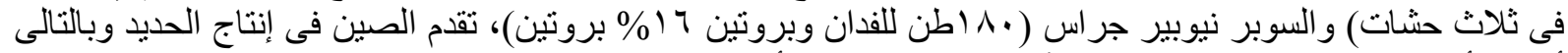

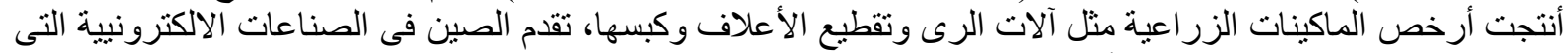

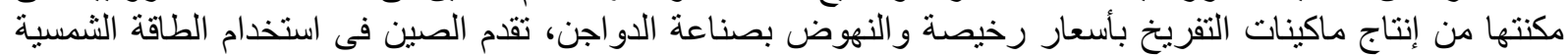

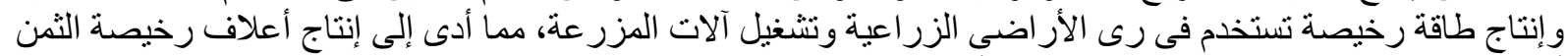

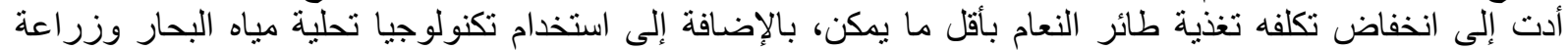

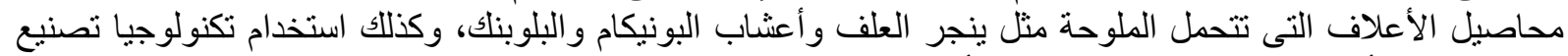

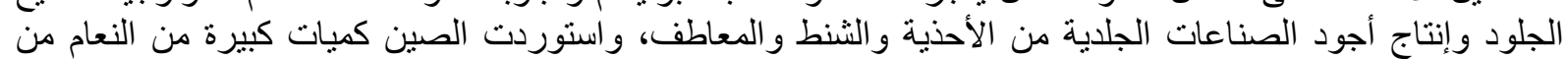

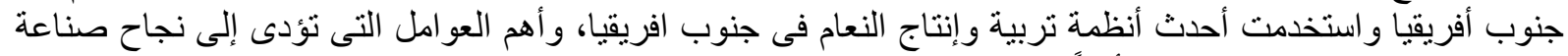

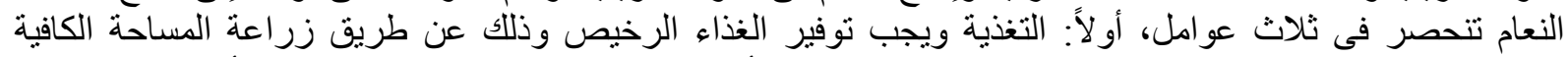

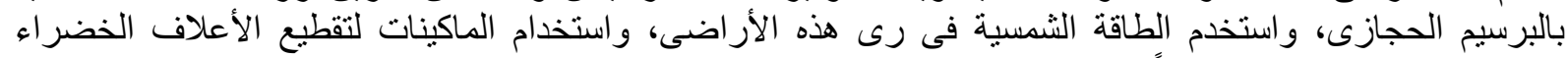

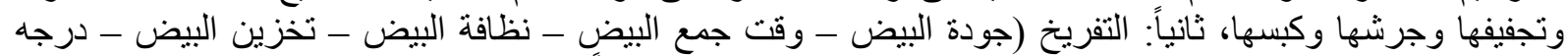

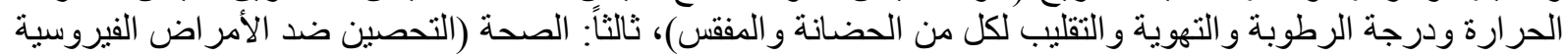
و البكتيرية و الفطرية و الطفيليات الداخلية و الخارجة). 